ENTITA : Jurnal Pendidikan Ilmu Pengetahuan Sosial dan Ilmu-Ilmu Sosial http://ejournal.iainmadura.ac.id/index.php/entita

P-ISSN:2715-7555 E-ISSN:2716-1226

\title{
Perubahan Sosial Masyarakat Pasca Dibangunnya Pabrik Rokok Mahayana di Desa Sumbersuko Kecamatan Tajinan Kabupaten Malang
}

\author{
Lilis Yuliana \\ Program Studi Pendidikan IPS, FIS, Universitas Negeri Malang \\ yulianalilis10@gmail.com \\ I Nyoman Ruja \\ Program Studi Pendidikan IPS, FIS, Universitas Negeri Malang \\ nyoman.ruja.fis@um.ac.id \\ Nurul Ratnawati \\ Program Studi Pendidikan IPS, FIS, Universitas Negeri Malang \\ nurul.ratnawati.fis@um.ac.id
}

\begin{abstract}
Indonesia is a developing country. However, along with development, it is possible that Indonesia

will become a developed country. This can happen when industrial development is getting faster.

The existence of an industrial area in an area will provide changes in livelihoods. This will help in improving the economic standard of the community. Industrial developments that cause changes can also be observed in Sumbersuko Village, T Crafts District, Malang Regency. The focus of this research is: (1) The background of the establishment of a cigarette factory in Sumbersuko Village, $T$ Crafts District, Malang Regency. (2) Social changes that occur after the construction of a cigarette factory. (3) Contribution made by the Mahayana cigarette factory to the community. This research uses a qualitative approach with a descriptive type. The location of research that will be carried out by researchers is in the cigarette factory industry PT Karya Timur. Sources of data in this study are primary data sources and secondary data sources. The technique of determining informants in this study was using the Snawball Sample. Data collection methods used in this study were interviews, observation, and documentation. Data analysis in this study includes the stages of data collection, data reduction, data presentation, verification and drawing conclusions. The results of this study are first, the occurrence of changes in society after the construction of the cigarette factory industry. Changes that occur in society are related to a lifestyle that is getting better than before. Such changes include changing the work of the community from farmers to factory employees. Second, people's lifestyle related to clothing models that are increasingly glamorous and have a consumptive attitude. As well as more than 1 means of transportation owned by the community which is very supportive of activities in daily life. Apart from that, the Mahayana cigarette factory also contributes to society. The contribution given is in the form of new jobs for the surrounding community. Second, the existence of public facilities such as lighting along the roads, road construction assistance and public facilities such as prayer rooms and mosques. Third, there is basic food assistance, distribution of meat during Eid al-Adha. And there is an Umrah package reward for employees who produce a lot and are disciplined at work.
\end{abstract}

Keywords: Social Change, Cigarette Factory

\section{Abstrak}

Indonesia merupakan salah satu negara berkembang. Namun seiring perkembangan, tidak menutup kemungkinan bahwa Indonesia akan menjadi negara maju. Hal itu dapat terjadi ketika perkembangan industri semakin pesat. Keberadaan kawasan industri di suatu wilayah akan memberikan perubahan mata pencaharian. Hal ini akan membantu dalam peningkatan taraf 
ekonomi masyarakat. Perkembangan industri yang menyebabkan perubahan juga dapat diamati di Desa Sumbersuko Kecamatan Tajinan Kabupaten Malang. Adapun fokus penelitian ini yaitu: (1) Sejarah berdirinya pabrik rokok di Desa Sumbersuko Kecamatan Tajinan Kabupaten Malang. (2) Perubahan sosial yang terjadi setelah dibangunnya pabrik rokok. (3) Kontribusi yang diberikan pabrik rokok Mahayana terhadap masyarakat. Penelitian ini menggunakan pendekatan kualitatif dengan jenis deskriptif. Lokasi penelitian yang akan dilakukan oleh peneliti adalah di industri pabrik rokok PT Karya Timur. Sumber data pada penelitian ini adalah sumber data primer dan sumber data sekunder. Teknik penentuan informan dalam penelitian ini menggunakan Snawball Sample. Metode pengumpulan data yang digunakan dalam penelitian ini adalah wawancara, observasi, dan dokumentasi. Analisis data dalam penelitian ini meliputi tahap pengumpulan data, reduksi data, penyajian data, verifikasi dan penarikan kesimpulan. Hasil dari penelitian ini adalah pertama, terjadinya perubahan di masyarakat pasca dibangunnya industri pabrik rokok. Perubahan yang terjadi di masyarakat yakni terkait gaya hidup yang semakin baik dari pada sebelumnya. Perubahan tersebut seperti, beralihnya pekerjaan masyarakat dari petani menjadi karyawan pabrik. Kedua, gaya hidup masyarakat terkait model pakaian yang semakin glamour dan memiliki sikap konsumtif. Serta alat transportasi yang dimiliki masyarakat lebih dari 1 yang sangat menunjang kegiatan dalam kehidupan sehari-hari. Selain itu, pabrik rokok Mahayana juga memberikan kontribusi terhadap masyarakat. Kontribusi yang diberikan berupa lapangan pekerjaan baru bagi masayarakat sekitar. Kedua, adanya fasilitas umum seperti lampu penerangan sepanjang jalan, bantuan pembangunan jalan raya serta fasilitas umum seperti mushola dan masjid. Ketiga, adanya bantuan sembako, pembagian daging saat hari raya Idul Adha. Serta ada reward paket umroh bagi karyawan yang hasil produksinya banyak, dan disiplin dalam bekerja.

Kata Kunci : Perubahan Sosial, Pabrik Rokok

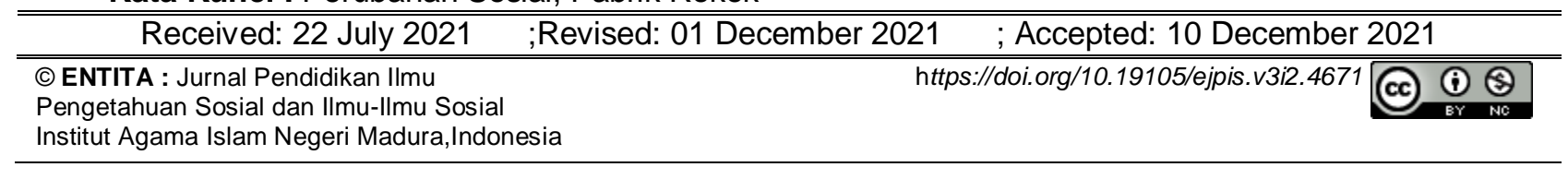

\section{Pendahuluan}

Indonesia merupakan salah satu negara berkembang. Ciri negara berkembang antara lain masih rendahnya kualitas penduduk dalam segi pendidikan. Selain itu, dalam segi ekonomi seperti kebutuhan pokok masih bergantung pada negara lain. Perluasan dan perkembangan industri telah nampak hampir keseluruh wilayah di Indonesia (Sztompka, 2008). Adanya perkembangan industri dapat memberikan pengaruh terhadap kehidupan masyarakat. Industrialisasi juga bisa diartikan sebagai suatu keadaan dimana masyarakat berfokus pada ekonomi yang meliputi pekerjaan yang semakin beragam serta penghasilan yang semakin tinggi. Tujuan dari adanya industrialisasi adalah terciptanya lapangan pekerjaan, pengembangan wilayah serta pemanfaatan sumber daya alam yang ada. Selain itu, keberadaan industri di suatu wilayah akan mempengaruhi terhadap masyarakat berupa nilai-nilai serta pengaruh fisik terhadap masyarakat (Syani, 2007).

Adanya perubahan mata pencaharian dikarenakan pekerjaan yang sebelumnya dirasa masyarakat tidak dapat mencukupi lagi akibat berkurangnya lahan pertanian serta penghasilan yang didapat tidak tetap (Siska, 2013).

Terdapat penelitian terdahulu sebagai acuan dalam penelitian ini. Pertama, penelitian dari Prasetyaningtyas (2016) dari Universitas Negeri Malang yang meneliti 
tentang "Perubahan Sosial Masyarakat Tengger dengan Kedatangan Wisatawan Bromo di Desa Ngadas Kecamatan Ngadas Kabupaten Malang". Hasil dari penelitian menunjukkan bahwa mata pencaharian warga sekitar yang utamanya sebagai petani beralih menjadi guide. Kedua, penelitian yang dilakukan oleh Anhar (2018) dengan judul "Perubahan Sosial Pasca dibangunnya Wisata Agropolitan di Desa Poncokusumo, Kecamatan Poncokusumo, Kabupaten Malang". Hasil dari penelitian ini yaitu berkembangnya potensi pertanian yang mampu meningkatkan taraf hidup masyarakat. (Anhar, 2018)

Ketiga, dilakukan oleh Firmansyah (2018) dengan judul "Perubahan Sosial Ekonomi Pekerja Sentra Industri Batik di Desa Kunir Kidul Kecamatan Kunir Kabupaten Lumajang". Hasil dari penelitian ini yaitu terdapat perubahan pada perilaku produktif oleh masyarakat pekerja wanita. Pengaruh fleksibelitas kerja oleh sentra industri batik, membuat para pekerja wanita melakukan pekerjaan produktif disela pekerjaan produktif lainnya. Berdasarkan pemaparan di atas maka dapat diambil fokus penelitian sebagai berikut: (1) Sejarah berdirinya pabrik rokok di Desa Sumbersuko Kecamatan Tajinan Kabupaten Malang. (2) Perubahan sosial yang terjadi setelah dibangunnya pabrik rokok. (3) Kontribusi yang diberikan pabrik rokok Mahayana terhadap masyarakat.

\section{Metode Penelitian}

Jenis penelitian yang digunakan dalam penelitian ini adalah penelitian deskriptif (descriptive research). Penelitian menggunakan deskriptif kualitatif bertujuan untuk menggambarkan, meringkaskan berbagai kondisi serta berbagai fenomena realita sosial yang ada di masyarakat yang menjadi objek penelitian. Lokasi yang dijadikan sebagai objek penelitian adalah Pabrik Rokok Mahayana di Desa Sumbersuko. Penelitian tentang "Perubahan Sosial Masyarakat Pasca Berdirinya Pabrik Rokok Mahayana Di Desa Sumbersuko Kecamatan Tajinan Kabupaten Malang". Data dan informasi diperoleh dari informan kunci yaitu masyarakat Desa Sumbersuko yang bekerja di pabrik rokok. Data dan informasi yang terkumpul selanjutnya dianalisis dengan model analisis interaktif Miles dan Huberman, yang terdiri dari pengumpulan data, reduksi data, penyajian data, dan penarikan kesimpulan.(Creswell, 2014)

\section{Hasil dan Pembahasan \\ Sejarah berdirinya pabrik rokok Mahayana}

Indonesia merupakan negara agraris yang memiliki penghasilan terbesar dari sektor pertanian. Pertanian sangat membantu masyarakat karena perekonomian yang ada bergantung pada hasil panen. Matapencaharain utama masyarakat adalah petani atau buruh tani. Lahan pertanian yang luas merupakan aset masyarakat untuk menghasilkan pendapatan dalam mencukupi kebutuhan sehari-hari (Prasetyaningtyas, 2016). Seiring 
perkembangan zaman dan teknologi membuat pergesaran lahan pertanian yang beralih fungsi menjadi industri.

Industri merupakan salah satu faktor pendorong adanya kemajuan yang semakin pesat. Adanya industri memberikan perkembangan di bidang sosial ekonomi masyarakat yang semakin meningkat. Kini, industri yang ada di Negara Indonesia semakin berkembang bahkan telah nampak hampir keseluruh wilayah di Indonesia (Sztompka, 2008).

Berdasarkan hasil penelitan yang telah dilakukan pembangunan pabrik rokok Mahayana dilakukan pada tahun 19 April 2004. Saat itu pabrik rokok Mahayana masih menyewa gedung di RT 10 RW 03 Desa Sumbersuko karena belum memiliki gedung pribadi untuk produksi rokok. Pabrik ini menyewa gedung di daerah ini karena saat itu tidak ada lahan yang disewakan. Lahan yang kosong seperti sawah, tegal dan pekarangan masih dikelola sendiri oleh masyarakat untuk mencari nafkah sehari-hari. Pabrik ini menyewa gedung milik $\mathrm{H}$. Endang kurang lebih selama 5 tahun. Seiring perkembangan hasil produksi yang semakin banyak dan pendapatan rokok meningkat sehingga pihak pabrik dapat membeli lahan kosong untuk digunakan sebagai pabrik utama.

Pada awalnya pabrik ini hanya memproduksi rokok merk Mahayana saja dan masih milik perorangan. Sekitar lima tahun kemudian yakni ditahun 2009 pabrik ini sudah menjadi CV Karya Timur. Tahun itu lokasi pabrik sudah pindah ke sebelah barat yang gudangnya sudah milik pribadi bukan sistem sewa gedung. Di tahun selanjutnya pabrik semakin mengalami perkembangan sehingga menjadi PT Karya Bersama Tlogowaru Makmur. Adanya pabrik rokok Mahayana di desa ini membawa pengaruh positif bagi masayarakat. Hasil temuan peneliti ini senada dengan penelitian yang dilakukan oleh Baehaqi (2014) industri disuatu daerah dalam kategori kecil maupun besar akan memberikan pengaruh dan perubahan terhadap kehidupan masyarakat.(Baehaqi, 2014).

Pabrik rokok Mahayana yang berada di bawah naungan PT Karya Bersama Tlogowaru Makmur dan dapat memproduksi 2 merk rokok yakni Mahayana (kretek) dan Potenza (filter). Jumlah karyawan lebih dari 500-800 karyawan pabrik. Karyawan tersebut terbagi atas karyawan giling, packing dan mesin. Karyawan terbanyak terdapat pada bagian giling karena prosesenya manual dan lebih rumit serta membutuhkan ketelitian. Proses kedua yakni pada packing. Packing merupakan pengepakan rokok menggunakan kotak kardus yang disealer. Proses mesin yakni penyaringan kembali tembakau yang kualitasnya kurang bagus. Proses dengan mesin sangatlah membantu produksi rokok untuk mencapai target. Berbagai kegiatan dan pekerjaan dapat dilakukan dalam waktu singkat karena kecanggihan teknologi (Martono, 2014). 


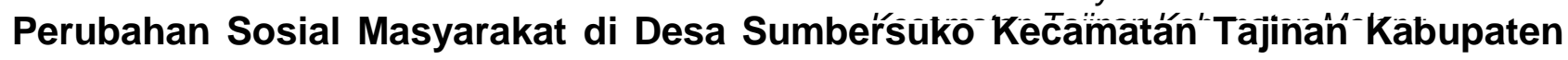 Malang Setelah Dibangunnya Pabrik Rokok}

Pembangunan industri pabrik rokok pada suatu wilayah pastinya akan memberikan suatu pengaruh. Pengaruh tersebut berupa hal yang kecil bahkan besar yang bisa menyebabkan suatu perubahan sosial. Perubahan sosial yang terjadi dapat berupa sesuatu yang terjadi pada masyarakat yang mempengaruhi pola kehidupan masyarakat serta nilainilai dan kelembagaan yang ada di dalamnya (Soekanto, 2012). Perubahan yang terjadi di masyarakat yakni terkait gaya hidup yang semakin baik dari pada sebelumnya. Salah satunya beralihnya pekerjaan masyarakat yang awalnya petani beralih menjadi karyawan pabrik rokok. Alasan mereka beralih pekerjaan karena dirasa kerja sebagai karyawan jauh lebih nyaman dan upah yang diberikan sesuai dengan pekerjaan yang dilakukan. Rasa tidak puas menyebabkan terjadinya perubahan. Karena ketidakpuasan tersebut menimbulkan perlawanan atau berbagai upaya untuk mengubahnya (Martono, 2014).

Perubahan alih pekerjaan tersebut didasari atas perilaku seseorang untuk melakukan alternatif pekerjaan lain yang lebih menguntungkan. Antara lain manfaatnya yaitu terbukanya lapangan pekerjaan yang dapat menghilangkan status masyarakat sebagai pengangguran dan terjadinya perubahan mata pencaharian masyarakat pekerja. Selain itu juga merupakan solusi untuk meningkatkan kesejahteraan ekonomi masyarakat setempat.

Selain perubahan tersebut, juga terdapat perubahan sosial yang membuat masyarakat memiliki gaya hidup konsumtif. Hal tersebut dibuktikan dengan pola gaya hidup dari segi pakaian. Sebelum adanya pabrik rokok, masyarakat cenderung sederhana dalam berpakaian. Namun, pasca berdirinya pabrik tersebut masyarakat yang bekerja sebagai karyawan akan mendapatkan upah gaji yang cukup. Sehingga mereka dapat memenuhi segala kebutuhan primer, sekunder bahkan tersier. Menurut Wahyudi (2013) perilaku konsumtif adalah perilaku seseorang yang cenderung matrelialistik, keinginan besar untuk memiliki benda-benda berkualitas tinggi yang hanya untuk kesenangan semata meskipun tidak terlalu dibutuhkan. Apalagi saat ini didukung oleh perkembangan zaman yang semakin canggih. Seperti halnya banyaknya online shop juga salah satu faktor pendorong sikap konsumtif karena masyarakat secara mudah dapat berbelanja dimanapun dan kapanpun. Pola perilaku konsumtif yang dialami masayarakat karena adanya pemenuhan kebutuhan yang didapat secara praktis dan efisien (Indracahya, 2019).

Perubahan sosial terkait gaya hidup dalam model berpakaian terbukti nyata. Hal tersebut dibuktikan dengan adanya masyarakat yang selalu berkeinginan untuk membeli 
barang-barang baru. Masyarakat cenderung bersikap lebih mengutamakan keinginan atau hasrat (desire) dari pada kebutuhan (need). Menurut Fadilah (2013) kesejahteraan masyarakat dapat dilihat dari perubahan model pakaian, transportasi,serta kebutuhan yang lainnya.

Dari segi transportasi dapat dilihat memang terjadi perubahan. Transportasi merupakan komponen utama dalam sistem hidup dan kehidupan, sistem pemerintahan, dan sistem kemasyarakatan (Susantoro \& Parikesit, 2014). Sesuai dengan data yang didapatkan dari hasil wawancara dilapangan menjelaskan bahwa masyarakat memiliki lebih dari 1 alat trasportasi. Mereka mampu membeli kendaraan lebih dari satu karena sudah memiliki keuangan yang cukup. Gaji yang diperoleh sangat menunjang kebutuhan kehidupan sehari-hari masyarakat. Di sisi lain, transportasi memang berperan penting dalam aktivitas manusia. Jika alat transportasi sudah terpenuhi sesuai kebutuhan maka aktivitas sehari-hari juga akan terlaksana dengan baik.

\section{Kontribusi Pabrik Rokok Mahayana Terhadap Masyarakat.}

Industri pabrik rokok Mahayana yang telah dibangun di Desa Sumbersuko Kecamatan Tajinan tentunya memberikan pengaruh. Pengaruh tersebut sedikit banyak akan dirasakan masyarakat sebagai suatu kontribusi dari pabrik. Kontribusi merupakan suatu tindakan seseorang yang memberikan dampak positif maupun negatif kepada pihak lain (Wulandari, 2018). Sesuai dengan hasil penelitian dapat dijelaskan bahwa kontribusi dari pabrik rokok ini sangat bermanfaat bagi masyarakat setempat.

Pertama, adanya lapangan pekerjaan baru bagi masyarakat. Lapangan pekerjaan ini akan mengurangi jumlah pengangguran yang ada serta juga merubah alih pekerjaan masyarakat. Pendapat tersebut sejalan dengan hasil penelitian yang dilakukan oleh Rudi Firmansyah (2018) bahwa adanya lapangan pekerjaan baru akan mengurangi jumlah status pengangguran masyarakat.(Firmansyah, 2018)

Kedua, adanya bantuan untuk fasilitas umum seperti lampu penerang jalan dan juga perbaikan jalan. Hal tersebut merupakan beberapa kontribusi yang diberikan pabrik rokok terhadap masyarakat. Kontribusi yang berkaitan dengan fasiltas umum tentunya sangat bermanfaat dan membantu bagi masyarakat. Fungsi pembelanjaan digunakan untuk pengembangan perumahan, pemberdayaan komunitas fasilitas umum, penyediaan air minum, penerangan jalan, jembatan, jalan raya, rumah sakit dan gedung sekolah.

Ketiga, kontribusi terkait kebutuhan pokok seperti sembako bagi masyarakat. Pembagian sembako sebagai kebutuhan pokok masyarakat diberikan saat Hari Raya Idul 218 
Fitri dan pembagian daging qurban saat Idul Adha. Keberadaan industri pabrik rokok Mahayana tentunya juga ikut andil dalam mensejahterakan kehidupan masyarakat. Kesejahteraan masyarakat dapat diukur dari pemenuhank butuhan yang tercukupi dari segala aspek. Selain itu, terdapat jaminan kesehatan bagi semua karyawan pabrik rokok Mahayana.

\section{Kesimpulan}

Pembangunan pabrik rokok Mahayana dilakukan pada tahun 19 April 2004. Sekitar tahun 2009 pabrik rokok Mahayana pindah ke gudang baru yang resmi milik pribadi. Pada awal tahun 2009 pabrik ini masih CV Karya Timur. Setelah beberapa tahun pabrik rokok Mahayana terus mengalami peningkatan sehingga berubah menjadi PT. Pabrik ini berada di bawah naungan PT Karya Bersama Tlogowaru Makmur. Produk yang dihasilkan yaitu rokok Mahayana (kretek) dan Potenza (filter).

Pembangunan industri pabrik rokok pada suatu wilayah pastinya akan memberikan suatu pengaruh. Perubahan yang terjadi di masyarakat yakni terkait gaya hidup yang semakin baik dari pada sebelumnya. Perubahan tersebut seperti, beralihnya pekerjaan masyarakat dari petani menjadi karyawan pabrik. Gaya hidup masyarakat terkait model pakaian yang semakin glamour dan memiliki sikap konsumtif. Ketiga, alat transportasi yang dimiliki masyarakat lebih dari 1 dan sangat menunjang kegiatannya.

Selain itu, pabrik rokok Mahayana juga memberikan kontribusi terhadap masyarakat. Kontribusi yang diberikan berupa lapangan pekerjaan baru bagi masayarakat sekitar. Kedua, adanya fasilitas umum seperti lampu penerangan sepanjang jalan, bantuan pembangunan jalan raya serta fasilitas umum seperti mushola dan masjid. Ketiga, adanya bantuan sembako, pembagian daging saat hari raya Idul Adha. Serta ada reward paket umroh bagi karyawan yang hasil produksinya banyak, dan disiplin dalam bekerja.

\section{Saran}

Saran untuk penelitian selanjutnya lebih memfokuskan pada dampak para karyawan yang bekerja di pabrik rokok terhadap kesehatan.

\section{Referensi}

Buku

Anhar, K. (2018). Perubahan Sosial Pasca dibangunnya Wisata Agropolitan di Desa Poncokusumo, Kecamatan Poncokusumo, Kabupaten Malang. (Skripsi). Universitas Negeri Malang.

Baehaqi, S. (2014). Dampak Industri Perkebunan Kelapa Sawit Pada Perubahan Sosial 
Masyarakat Desa Ruhui Rahayu Kecamatan Tanjung Palas Utara Kabupaten Bulungan. Jurnal Sosiologi, 2(4). https://ejournal.sos.fisip-unmul.ac.id/site/wpcontent/uploads/2014/11/JURNAL\%20\%20SIDIQ\%20BAEHAQI\%20(11-18-14-0319-06).pdf

Creswell, J. W. (2014). Research Design Pendekatan Kualitatif, Kuantitatif, dan Mixed. Pustaka Pelajar.

Firmansyah, R. (2018). Perubahan Sosial Ekonomi Pekerja Sentra Industri Batik di Desa Kunir Kidul Kecamatan Kunir Kabupaten Lumajang. Skripsi Universitas Negeri Malang.

Martono, N. (2014). Sosiologi Perubahan Sosial: Perspektif Klasik, Modern, Postmodern, dan Postkolonial. Rajawali Press.

Prasetyaningtyas, N. D. (2016). Perubahan Sosial Masyarakat Tengger dengan Kedatangan Wisatawan Bromo di Desa Ngadas Kecamatan Ngadas Kabupaten Malang. Skrpsi Universitas Negeri Surabaya.

Siska. (2013). Dampak Industri Batu Bara Terhadap Sosial Ekonomi Masyarakat di sekitar Desa Jembayan Kecamatan Loa Kulu Kabupaten Kutai Kartanegara. Jurnal

Administrasi Negara, 1(2). http://ejournal.an.fisip-unmul.co.id/site/wp-content/upload

Susantoro, B., \& Parikesit, D. (2014). Langkah Kecil yang Kita Lakukan Menuju Transportasi yang Berkelanjutan. Majalah Transportasi Indonesia, Vol. 1.

Syani, A. (2007). Sosiologi dan Perubahan Masyarakat. Pustaka Jaya.

Sztompka, P. (2008). Sosiologi Perubahan Sosial. Prenadamedia Group.

Wulandari, S. (2018). Kontribusi Pendapatan Usaha Kopra Terhadap Pendapatan Rumah Tangga Petani Di Kabupaten Tanjung Jabung Timur. Jurnal Media Agribisnis, 3(2). 